\title{
Electronic Commerce in Tourism in China: B2B or B2C?
}

\author{
Hongxiu $\mathrm{Li}^{1}$, and Reima Suomi ${ }^{2}$ \\ 1 Information Systmes Instutute, Turku School of Economics \\ Turku Center for Computer Science \\ Joukahaisenkatu 3-5 B, 20520 Turku, Finland \\ Hongxiu.1i@tse.fi \\ 2 Information Systmes Instutute, Turku School of Economics \\ Rehtorinpellonkatu 3, 20500 Turku, Finland \\ Reima.suomi@tse.fi
}

\begin{abstract}
E-commerce has significantiy changed the distribution channels of travel products in the world including China. Online channels are growing important in travel service distribution. In China tourism industry has been developed rapidly with the economic development, more and more international travel service providers are trying to expand their Chinese market through the Internet. This paper sheds lights on the e-commerce development models in China for international travel service providers. It explores the current e-tourism in China from the three different participants in the value chain in tourism industry - consumer, travel agent and travel service provider. The paper also identifies the barriers in $\mathrm{B} 2 \mathrm{C}$ arena in international outbound travel market, and discusses the possible approaches for international travel service providers to develop their e-commerce in the huge Chinese market. The results in this study reveal that international travel service providers should focus on B2B model to expand their electronic market in China. B2C development in tourism largely depends on the change of Chinese customers' behavior and the change of international tourism regulations. The findings of the study are expected to assist international travel service providers to understand current e-tourism in China and to support their planning for future e-commerce development in China.
\end{abstract}

\section{Introduction}

With the Internet as a commercial medium, new ways of conducting business have developed in almost every sector. In the travel and tourism industry, new and

Please use the following format when citing this chapter:

I,i, H., Suomi, R., 2007, in IFIP International Federation for Information Processing. Volume 252, Integration and Innovation Orient to E-Society Volume 2, ods. Wang, W., (Boston: Springer), pp. 103-112. 
efficient Internet business models, including both B2B and B2C, have gained a strong foothold. The Internet has a tremendous impact on today's travel and tourism industry on both domestic travel and international travel, and the travel industry is ranked as the prime sector in e-commerce [1]. In the past several years, online transactions in the travel and tourism industry are continuously growing with the proliferation of e-commerce [2]. With these changes, customers' behavior is also changing, which is different in nature from the behavior of traditional customers due to the unique characteristics of the Internet and the interaction of technology and culture [3]. Customers are using both online and offline channels to book travel services.

In China tourism industry has been developed rapidly with the economic development, especially in international travel, which has attracted international travel service providers to develop their market in the huge Chinese market through the Internet. Some researches have been conducted on the e-commerce benefits, consumer behavior, evaluation of websites in travel industry in China, but the ecommerce development model in tourism industry in China, especially for international travel service providers around the world, has not been explored.

This paper attempts to investigate current e-commerce development in tourism industry in China and aims to find the proper e-commerce development model in China for international travel service providers. It explores the current electronic tourism (E-tourism) in China from the consumer, travel agent and travel service provider perspectives. This paper also identifies the barriers in $\mathrm{B} 2 \mathrm{C}$ arena in international outbound travel market and discusses the possible approach for international travel service providers to develop their e-commerce in the huge Chinese market. This study has been completed based on interviews and survey conducted both in China and Europe. The findings of the study are expected to assist international travel service providers to understand current e-tourism in China and to support their planning for future e-commerce development in China.

\section{Background}

\subsection{Value chain in tourism in China}

The typical value chain in tourism consists of four components: travel service provider, travel operator, travel agent and traveler. The travel services provided by travel service providers can be distributed by the joint operation of travel operator and travel agent, or just by travel agent to traveler (See Figure 1) [4]. On the intermediary level, normally the travel operator plays the role as a wholesaler of travel service in the value chain, which integrates a number of different travel services and offers them as a packaged service to travel agent, since many travel services are composed of various services provided by different travel service providers. The travel agent is the retailer of travel service in the value chain, which tie prospective travelers and service providers together by handling the information flow among the different participants in the value chain, and selling the information 
to travelers [5].The value chain is based on the cooperation among travel service provider, travel operator and travel agent with the help of Global Distribution Systems (GDS). In China on the traditional value chain the intermediary function of travel operator is weaker compared to that of travel agent, and most travel agents have taken the responsibilities of the travel operators [6].

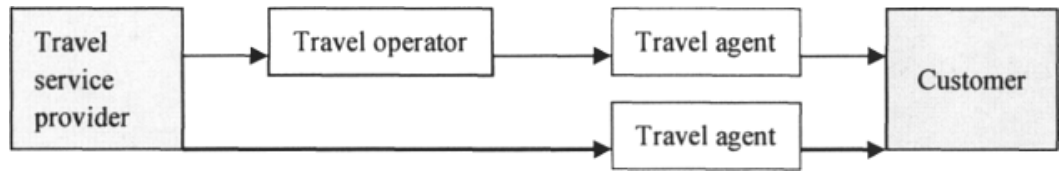

Figure 1. Traditional value chain in tourism

The last decade has witnessed the increased internationalization of the tourism industry because of the proliferation of e-commerce. All the participants in the traditional value chain in travel industry have been forced to seek global business strategies in order to generate a sustainable competitive advantage.

The travel service providers have adopted the Internet to offer online travel services to customers, including travel service searching and travel service booking (See Figure 2), which has been the responsibilities of the travel agents in the traditional value chain [7]. This is defined as the $\mathrm{B} 2 \mathrm{C}$ e-commerce model. Benjamin and Wigand (1995) have hypothesized the disintermediation prediction from a costbased perspective. There appears to be strong economic incentives for both travel service providers and customers to drive intermediaries (travel operator and travel agencies) out of the tourism value chain - for travel service providers to reduce transactional cost and for customers to get a reduced price. Further, the travel service provider can dominate the price and quality of their services, which can reduce the uncertainties of consumers [8,9].

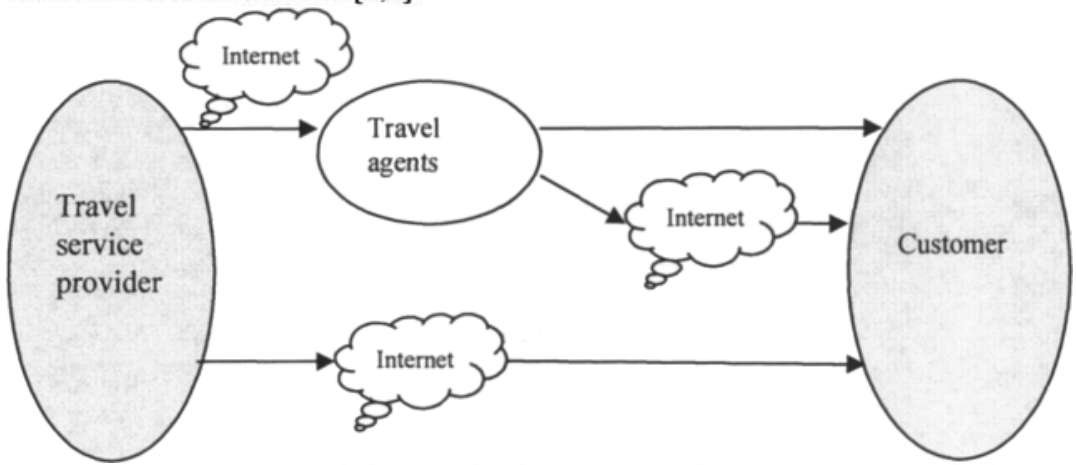

Figure 2. Combined Value Chain in tourism in e-commerce times

The disintermediation argument focuses primarily on the cost of intermediation, and the values that can be added by intermediaries are ignored. Sargar et al (1995) state that intermediaries should not be seen as pure transaction cost minimizing actors. They often add value to transactions by providing intensive services [10]. 
Travel agents have also used the Internet to develop differentiated value proposition and to reinforce their intermediary position in the tourism value chain. Travel agents are still the intermediaries in tourism value chain combined with the Internet (See Figure 2) [11]. The cooperation between travel service providers and travel agents based on Internet is the $\mathrm{B} 2 \mathrm{~B}$ business model in e-commerce.

In E-tourism, both $\mathrm{B} 2 \mathrm{~B}$ and $\mathrm{B} 2 \mathrm{C}$ models have offered great opportunities for international travel service providers to promote their travel service to customers directly or indirectly through the Internet. The Internet has typically helped travel service providers and travel agents out of the spatial and temporal limitation in business.

\subsection{E-tourism in China}

China's tourism industry has developed quickly in the past 20 years. In China since 1999 the government has put effort on further pushing tourism development by establishing three "Golden weeks" holidays, which has impelled both the domestic and international tourism development in China. According to the statistics of China National Tourism Administration (CNTA), since 2001 there is great increase on the number of outbound travelers and inbounds travelers. In 2006 the amount of outbound travels in China has arrived at 34.52 million (See Table 1). CNTA expects that in 2020 there will be about 210 to 300 million inbound tourists and 100 million outbound departures in China. World Tourism Organization (UNWTO) also predicts that China's tourism industry will take up to 8.6 percent of world market share and become the world's top tourism industry by 2020 . The outbound travelers from China will be the main source of international travelers in the world [12]. The great growth in outbound travel market in China has attracted international travel service providers around the world to promote their services in the huge Chinese market for more business profits.

Table 1. The numbers of outbound travelers in China from 2001 to 2006 M: Million

\begin{tabular}{lllllll} 
& 2001 & 2002 & 2003 & 2004 & 2005 & 2006 \\
\hline Outbound & $12 \mathrm{M}$ & $16.6 \mathrm{M}$ & $20.22 \mathrm{M}$ & $28.5 \mathrm{M}$ & $31.02 \mathrm{M}$ & $34.52 \mathrm{M}$ \\
\hline
\end{tabular}

Source: CNTA

In the past several years the e-commerce market in China has expanded rapidly with the increase of the population of Internet users in China. According to the survey conducted by China Internet Network Information Center (CNNIC), the number of Internet users in China has reached 137 million, and the number of websites has arrived at 843 thousand until the end of 2006 . The Internet users in China are mainly under 35 years old, and they often use the Internet to search information, read news and receive/send e-mails [13]. With the e-commerce expansion, the value of e-commerce is also growing in China. According to the survey conducted by China Market Information Centre (CCID), in China the revenue generated in e-commerce has arrived at $\$ 137.5$ billion in 2006 with an increase rate of $52 \%[14]$. 
The e-commerce development and the expansion of electronic market in China bring both challenges and opportunities for travel organizations in tourism industry in the world. Although the Internet has become an important travel service delivery channel, e-tourism in China is still at its initial stage [3]. In China, travel organizations have moved more and more activities and services online to attract more customers and guide their activities [6]. But only around $8.6 \%$ of Internet users are using the Internet to book travel service [13]. Under the high profitability pressure some online travel agencies have to combine both offline and online service delivery to keep competitive in the market, for example Elong.com and Ctrip.com. Chinese customers still rely more on the traditional intermediary - travel agencies to book travel service. The electronic market in tourism is still not so good compared to some other developed countries [6]. In 2006 the Chinese government has started the Golden Tourism project, which aims at pushing e-tourism development in China.

\section{Method}

This research aims to explore the issue on the e-commerce development model in China for international travel service providers. Since the study is focusing on the ecommerce development model in tourism in China, which is involved in both the supply side and the customer side. In this study both qualitative and quantitative approaches are adopted. The study issue is investigated based on the data collected form the three different participants in the combined value chain in tourism in ecommerce times: travel service provider, travel agent and customer.

In this study interviews were conducted to explore the perceptions of ecommerce development model on both travel service providers and travel agents perspectives. Some qualitative data were collected from interviews conducted in 9 companies - 1 travel service provider and 8 travel agencies. The travel service provider is an international airline company in Europe, and the 8 travel agencies are big international travel agencies in Beijing, Shanghai, Guangzhou and Shanghai in China, which have cooperation with the international airline company.

Totally 15 interviews were conducted -6 in the international airline company and 9 in travel agencies (See Table 2). Among the 6 interviewees in the international airlines, three of them are sales managers in China, one is the manager of the ecommerce department, one is the manager of the revenue and pricing department, and one is the project director of the e-commerce department. Among the 9 interviewees in the tour agencies, 4 of them are general managers or deputy general managers, and 5 of them are sales department managers or directors.

Table 2. Formal Interviews

\begin{tabular}{lll}
\hline & Number of companies & Number of interviewees \\
\hline International airlines & 1 & 6 \\
\hline Travel agencies in China & 8 & 9 \\
\hline We compiled two different lists of questions depending on the different \\
investigated two interviewee groups - one list for the interviewees from the
\end{tabular}


international airlines and the other for the interviewees from travel agencies. Structured interviews were conducted in both groups. Before interviews, all the interviewees were informed of the interviewed topics in advance in order to make sure that they know about e-commerce in tourism and can offer some valuable data for this research. The interviewees were asked to express their perceptions of ecommerce development model in tourism in China. Every interview lasted around 1 hour.

In order to investigate customer's attitude towards online travel service booking in the B2C model, a quantitative survey was conducted in this study. In the survey a questionnaire was developed to collect empirical data. We chose some passengers of the interviewed international airlines in our study to investigate the customer perceptions of online travel service booking. The passengers were asked to report on their current use of the Internet to book travel service or search travel information, and their future intentions on online travel service booking. The survey was conducted by the airline company onboard. In the study totally 190 copies were received, and 169 copies are usable.

\section{Data analysis}

\subsection{Travel service provider perspective}

The e-commerce development in China was discussed with the interviewees from the international airlines, which helps to understand the travel service providers' perceptions on e-commerce development models in China. The Chinese customers of the international airlines are mainly group traveler, and individually customers take a small share in the Chinese market. Clearly all the interviewees agreed that for the international airline company its e-commerce in China is just at the beginning, and it still depends on the travel agencies and their sales offices in China to promote flight tickets though they have adopted e-commerce in their ticket sales. As regards to their e-commerce development models, the two interviewees from the ecommerce department stated that in China the international airlines is focusing on $\mathrm{B} 2 \mathrm{~B}$ business at the beginning and $\mathrm{B} 2 \mathrm{C}$ is developed as well, but currently $\mathrm{B} 2 \mathrm{C}$ is not their focus in China, since its B2C business in China has not achieved improvement compared to its B2B business. It is quite different from that in Europe. In fact in Europe its B2C business has performed very well. They agreed that there are barriers for their B2C development in China. The main barrier is the restricted visa regulations. Chinese citizens traveling to Europe for leisure should be in travel groups. They agreed that the Chinese customers' behavior and the e-commerce development in tourism industry in China is quite different from that in Europe. Chinese customers prefer group travel to DIY travel, and groups keep the main tourism model in China. They states that its e-commerce should be developed based on the nature of the Chinese market. Currently, the travel agencies are its main ticket sales channel in China. Thus currently good cooperation with travel agencies based on the B2B business will be more important for its business in Chinese market. 


\subsection{Travel agents perspective}

Travel agents, mainly travel agencies, are always important intermediaries in the value chain of tourism. Nowadays, travel agencies have adopted both B2B and B2C in their e-commerce development, which tie the travel service providers and customers. Travel agencies conduct business transaction with customers directly or through the Internet, which makes them know better about the customer behavior in tourism. According to the discussion with the interviewees from different travel agencies, they have some similar ideas on e-tourism development in China. They agree that in China travelers are mainly group travelers, especially in the outbound travel market, and the travelers are mainly between $25-40$ years old. Travel agencies in China are still the main intermediaries of travel service providers, especially the international travel service providers in the world. The 8 travel agencies have already conducted good B2B cooperation with different travel service providers around the world, including airlines, hotels and so on, which brings them convenience and save their time in working. The 8 travel agencies promote their travel services provided by travel service providers through both traditional channels and the Internet. Individual customer in their business is less than group customer in both domestic and international tourism. At present, 7 travel agencies focuses their e-commerce mainly on B2B, and only 1 travel agency is going to focus on both of them.

In the discussion the interviewees illustrated their barriers in developing $\mathrm{B} 2 \mathrm{C}$ in international travel service in China. Among the interviewees, 6 of them agreed that restricted visa regulation is the main barrier, which is similar to the opinions of the interviewees from the international airlines, and 4 of them stated that language is another obstacle. Most of the Chinese travelers are not good at English. The Chinese customers are not willing to get into trouble in their trip out of China. They prefer to go with travel groups in their outbound trip with more insurance of their trip. They also mentioned that the language barrier will disappear gradually with the enhanced internationalization in China.

\subsection{Customer perspective}

The customers are investigated on their online travel service booking experience, online travel service searching and online booking for future travel service in the $\mathrm{B} 2 \mathrm{C}$ arena. Among the 169 respondents, most of them (97.2\%) are Internet-users. And 99 of them have booked travel service online, accounting for $58.8 \%$ of all the respondents. As regards to travel information search, based on means comparison, travel agencies are ranked as the most important travel information searching channel and the Internet is not so important. (See Table 3).

For their future travel service booking, travel agencies are still more important than the Internet, $45.6 \%$ of the respondents are intended to use travel agency to book travel service and $33.1 \%$ of them will use the Internet to book their future trips. The investigated results on online bookers and potential online bookers are much higher than the results released by CNNIC.

Table 3. Travel information search channel 


\begin{tabular}{lll}
\hline & Mean & Std. Deviation \\
\hline Travel agency & 1.99 & 1.322 \\
Friends & 2.04 & 1.145 \\
Experience, habit & 2.29 & 1.486 \\
Internet & 2.31 & 1.316 \\
Advertisement & 3.24 & 1.522 \\
\hline
\end{tabular}

\section{Discussion and conclusion}

Travel industry is quite fit for e-commerce and the Internet because of its information-intensive nature. But in China e-tourism is still in its initial stage, which is different from that in Europe and in America, since the Chinese customers' behavior and the e-commerce development condition in China is different. The research findings in this study reveal that in China B2B business model will be popular than $\mathrm{B} 2 \mathrm{C}$ in both the domestic and international travel market. In the international travel market, the $\mathrm{B} 2 \mathrm{C}$ business model has been impeded by the language barrier from customers and the visa regulations from destinations countries. Though international travel service providers are eager to catch the opportunities that the Internet bring to them to expand their B2C market as in Europe or in America, it seems they have no power to solve the barrier of visa regulations.

According to the customers' perception, travel agencies keep the main intermediaries in tourism in China, though the Internet has become an important travel service booking channel. Travel agencies take the combined business model to offer travel services to customer - through both the traditional offline and the popular online service. The intensive travel services offered by travel agencies in the combined business model are not what travel service providers can offer to customers through their direct online sales. The results in the study state that half of the investigated customers will still book travel services from travel agencies, which is much higher than that of the Internet bookers for future trip. The results from customer survey are in consistent with the results from the interviews in travel agencies. At present the group travelers are the main customers of travel agencies. The share of online travel service booking from individual customers is less than the share of group travelers in traditional offline channels. The role of travel agency as the middleman in travel value chain will keep important.

In addition according to the results of the study, the age of the main outbound travelers in China are quite similar to the age of the main Internet users in China. It implies that in the future with the change of the international tourism regulations B2C should have its great potential in e-tourism since the main outbound travelers are also the main Internet users in China.

Based on the discussion we can arrived at the conclusion that e-commerce in China has a great potential for international travel service providers, currently international travel service providers, who are developing or planning to develop their e-commerce in China should mainly focus on B2B to expand their electronic market in China. B2C model development largely depends on the change of Chinese customers' behavior and the change of international tourism regulations. Appropriate 
e-tourism strategies based on the e-tourism condition in China can help international travel service providers to expand their Chinese market successfully.

The primary limitation of the study is that the empirical data collected is based on a small size of respondent, which is used to represent the general perceptions of customers in China with a large size of population. This study has provided an indepth knowledge about the e-tourism development in China, and offered some valuable guideline for both international travel service providers around the world. Future study should take into consideration of the factors that affect the adoption of booking travel online in China.

\section{Reference}

1. V.C.S. Heung, "Barriers to Implementing E-commerce in the Travel Industry: A Practical Perspective”, Hospitality Management 22(2003), 111-118 (2003).

2. H. Werthner, and F. Ricci, "E-commerce and Tourism", Communications of the $A C M 47(12), 101-105$ (2004).

3. L. Li, and D. Buhalis, "E-commerce in China: The Case of Travel", International Journal of Information Management 26(2006), 153-166 (2006)

4. M. Kaukal, W. Hopken, and H. Werthner, "An Approach to Enable Interoperability in Electronic Tourism Market", In : Proceedings of International Conference of Information Systems (ECIS 2000). Vienna, Austria, 1104$1111(2002)$.

5. B. Anckar, and P. Walder, "Destination Maui? An Exploratory Assessment of the Efficacy of Self-Booking in Travel", Electronic Market 10(2), 110-119 (2000).

6. Jie $\mathrm{Lu}$, and $\mathrm{Zi} \mathrm{Lu}$, "Development, Distribution and Evaluation of Online Tourism Services in China", Electronic Commerce Research 4(2004), 221-239 (2004).

7. C. Wynne, and P. Berthon, "The Impact of the Internet on the Distribution Value Chain: The Case of the South African Tourism Industry", International Marketing Review 18(4), 420-431 (2001).

8. R. Benjamin, and R. Wigand, "Electronic Markets and Virtual Value Chain on the Information Superhighway", Sloan Management Review 36(2), 62-72 (1995).

9. G.M. Giaglis, K. Stefan, and R.M. O'Keefe, "The role of Intermediaries in Electronic Marketplaces: Developing a Contingency Model”, Information System Journal 12(2002), 231-246 (2002).

10. M.B. Sarkar, B. Butler, and C. Steinfield, "Intermediaries and Cybermediaries: A Continuing Role for Mediating Players in the Electronic Marketplace", Journal of Computer Mediated Communications 1(3), http://jcmc.huji.ac.il/voll/issue3/sarkar.html

11. K. Stefan, and R.A. Teubner, "Web-based Procurement New Roles for Intermediaries", Information Systems Frontier 2(1), 19-30 (2000).

12. Outbound Travel Development in China, http://www.cnta.gov.cn/news_detail/newsshow.asp?id=A20075101738546353446

13. China Internet Network Information Center (CNNIC), The 19th Statistical Survey of Internet Development in China, http://www.cnnic.net.cn/uploadfiles/pdf/2007/1/23/113114.pdf 
14. China Market Information Center (CCID). The Report of Internet Development in China 2007, http://market.ccidnet.com/pub/report/show_12636.html 